\title{
Migration policy and national minorities in the Republic of Lithuania: lessons for Ukraine
}

\begin{abstract}
The purpose of the article is to determine the factors that influenced the process of the development and implementation of Lithuania's foreign and domestic policies in the field of migration within the framework of the EU rules (dispositive and imperative) and identify those factors that may have a similar effect on the stability of migration processes in Ukraine with regard to its accession to the EU. The task is to determine the problems (negative preconditions and consequences) of the migration sector based on the analysis of more than a decade of experience of Lithuania as an EU member and the influence of the latest European crisis. Lithuania's strategies with regard to the following issues are relevant to Ukraine's European integration aspirations: the migration crisis in the EU, in terms of overcoming it through a "relocation plan;" and the integration of the national minorities of Lithuania, including the Roma minority, into the country's civil society. Furthermore, some of Lithuania's efforts actively support Ukraine's European integration aspirations, such as the attempt to model how current problems can be predicted and resolved by Ukraine if it acquires EU membership, on the basis of Lithuania's experience, which has relevance for Ukraine due to the fact that Lithuania and Ukraine - along Poland and other countries - inherited the Soviet system of government, and because of their similar mentality and current bilateral relations. After the Ukrainian crisis in 2014, and the subsequent EU migration crisis in 2015, Lithuania reviewed its national policy priorities taking into account that its state boundary is the part of the EU boundary, without any "buffer zone."
\end{abstract}

Key words: The Republic of Lithuania, migration policy, the EU migration crisis, national minorities, immigration, state language development

\section{Introduction}

$\mathbf{T}$ he EU migration policy covers a wide range of issues which include not only security - both humanitarian and economic, but also cultural, linguistic and social spheres. In the event of becoming an EU member, Ukraine will have to somewhat modify its practical approaches to settling the migration processes issue, which are currently different from the EU migration policy. It would therefore be useful to develop an appropriate strategy based on the experience of post-Soviet EU member states.

The Baltic states, including the Republic of Lithuania, did not play key roles in the settlement of the EU-wide migration crisis which started in 2015, for a number of reasons. Neither the geographic location, nor the level of the economy or political initiatives of the countries' leaders could be used as leverage for the Baltic states, in their dealings with the other EU member states; thus they were unable to show themselves as experts in dealing with peoples of the Middle East and their leaderships. Moreover, even prior to this, the crisis of 2014, which arose in Ukraine as a result of the illegal annexation of the Crimean Peninsula and the Donbas conflict, prompted the Lithuanian leadership not 
so much to engage in solving the problem as an "advocate" of Ukraine in the EU, as to review its own security prospects: from the completion of the demarcation of the common border with Russia which is, at the same time, part of the EU's eastern border, to the drafting of legislation that would strengthen the trust placed in the Lithuanian authorities by the members of many thousands of national minorities whose civic attitudes may influence, to some extent, the security situation inside the country.

Migration processes in the world occupy a key place among issues that raise new challenges, transforming humanitarian problems that had been until recently fully resolved on an international level into problems causing crises of a geopolitical, economic and social nature. As a consequence of membership in the European Union, each member state has to resolve the issue of migration policy at two levels simultaneously - internally and externally.

Such duality of responsibility sets the task before the Baltic states, in particular Lithuania, of ensuring, first and foremost, proper security within the country, since the presence of the speakers of foreign languages, who for the most part represent Polish and Russian national minorities, has some effect on the attitudes of civil society within all three countries. Today, migration problems in Lithuania are of a permanent nature, as the outflow of Lithuanian citizens from the country continues and potential danger from the eastern border of the country remains. The crisis in Ukraine, being a third party for the $\mathrm{EU}$, has intensified the process of labor migration to Lithuania, in contrast to the crisis in the Middle East that triggered solely economic and political illegal migration, which the Baltic states as EU members also have to face. But on the other hand, migration dynamics and recent policy decisions have resulted in the selective liberalization of the Lithuanian labor market for non-EU citizens like Ukrainians or Belarusians.

In the near future, Ukraine, as a potential member of the EU, will face similar problems, so even now the analysis of Lithuania's experience in the field of migration (especially with regard to preventative measures) will be of a practical nature. The problem of the migration policy of the Republic of Lithuania has not been thoroughly studied in Ukrainian science; it is usually included in the general foreign policy of the state. This article takes the following into account: the most basic principles of the migration system theory (de Haas, 2009), the network theory of international migration (Massey et al., 1993) and the theory of the border; a content analysis of the relevant information of 2014-2018 published in the leading mass media of Lithuania; academic research, official statements, and reports; and official documents of the EU, Lithuania, and Ukraine.

For the Republic of Lithuania, a country with a population of almost 3 million citizens, the migration policy includes a number of issues that need permanent resolution: restraining the labor migration of Lithuanian citizens to EU countries with better economic climates, the lack of labor migration of EU citizens to Lithuania, the active labor migration (legal and illegal) of Ukrainians to Lithuania, the economic and political migration of foreigners from the Middle East countries to the EU (so-called illegal immigrants), encouraging Lithuanians to return to Lithuania for permanent residence, the issue of the integration of foreigners into the public life of the Lithuanian state, settling the issue of the rights and freedoms of national minorities in Lithuania, and strengthening the protection of the Lithuanian state's eastern border, which is also the eastern border of the EU, etc. 


\section{Lithuanian border security in the context of the European crisis}

The Republic of Lithuania, like other Baltic states, does not fully fulfil the tasks set in 2015 by the European Commission with an aim of overcoming the migration crisis in the EU by quota resettlement of illegal migrants in its territory; but in formal terms, Lithuania's policy does not violate common EU law (Brunovskis, 2017, p. 8). There are two legitimate reasons to refuse an immigrant a residence permit in EU countries: if the person is potentially dangerous to the society of the country concerned, and if the person is potentially dangerous in the international security perspective (Perring, 2016). In addition, Lithuania individually insists that in the absence of the personal files (documents) of persons in need of international protection (not economic protection), the country is entitled to refuse such a request. In practice, most migrants do not have documents. As of July 2018, of the 1,105 migrants that Lithuania pledged to accept, only 468 were officially resettled to Lithuania (Jakučionis, 2018). Of these, 338 people have already left the country and moved to other EU member states, where the conditions of stay are more economically advantageous (Minister of Internal Affairs of Lithuania, 2018). If we compare the number of registered migrants and refugees in Spain in $2018-55,756$ thousand - and the number of those sent to Lithuania in 2018, we can conclude that not only is the Lithuanian position one of "disagreement" with the decision of Brussels, but also that the national migration policy prevails over the Union's one.

Then Vice-Minister of the Lithuanian government, Rimantas Vaitkus, expressed doubts about the feasibility of Lithuania's implementation of the Refugee Resettlement system (plan) due to the extremely low number of persons who would like to obtain legal status in Lithuania (Lithuania: EU resettlement programme triggers national social inclusion challenges, 2016). The disagreement of a part of the Lithuanian population with the migrants being resettled in Lithuania is explained not only by the experience of Lithuania having been inhabited by the peoples of the USSR (Geddes, Scholten, 2016, pp. 200-206), but also by the general sense of constitutional justice during the years of integration into the EU, which the leadership of the state must ensure. Simultaneously with the EU crisis, the 2015 Paris terrorist attack carried out by migrants has deepened the Lithuanians' beliefs about the dangers posed by migrants. A survey by the Lithuanian Institute for Ethnic Studies showed that Lithuanian citizens would prefer to accept migrants of similar cultures or, in other words, "migrants of the same race and origin" (Lithuania: EU resettlement programme triggers national social inclusion challenges, 2016).

In practice, the reasons for the ineffectiveness of Lithuania's integration policy for migrants when compared with Sweden or Germany can be identified solely through surveys of persons directly involved on both sides of the implementation and use of this policy: the representatives of relevant state bodies, NGOs, and asylum seekers/refugees themselves. The following reasons have been identified as belonging to the common vision of separate actors in the integration process in Lithuania:

- The conditions in the Foreigners/Refugees Reception Center do not provide foreigners with a good first impression of Lithuania: being located approximately $10 \mathrm{~km}$ from NATO's military base is psychologically unacceptable to many migrants;

- The increase in the duration of the refugee application process for ordinary applicants; the priority of examining the applications of persons arriving under the Migra- 
tion Resettlement Plan increases the length of stay in the Foreigners/Refugees Reception Center for ordinary applicants, which also complicates their further integration into Lithuanian society;

- The organization of the integration process at migrant registration and reception centers outside Lithuanian society creates a delay in actual integration;

- A lack of alternative housing outside of migrant reception centers;

- Low and short-term financial support for integration reduces the chances of successful integration into society;

- Insufficient time for learning the basics of the Lithuanian language. Additionally, interrelated integration in terms of granting, retraining or training refugees/asylum seekers; language and conditions are also not always the priority when it comes to the qualification of a person on the labor market (Brunovskis, Sønsterudbråten, 2017, pp. 35-36).

Lithuania's foreign policy for dealing with the EU migration crisis has formally been fully in line with the European Commission's Resettlement Plan, but paradoxically the low number of applications from Middle Eastern migrants has become the main reason for the inability to fulfil its obligations to the European Commission. Although the Lithuanian authorities, in their turn, made statements against the European Commission's decisions, all additional conditions for accepting migrants on its territory were still formally met.

In this regard, improving the security of the EU's external borders has become a key element of the EU's migration policy. In 2018, Lithuania submitted a proposal at a meeting of the European Council to establish a single standard of control at the EU's external borders, which will guarantee the removal of loopholes in the protection of the Community's land and maritime borders. This will strengthen the activities of the European Border and Coast Guard Agency (FRONTEX), in which Lithuanian experts are already working (EU Heads, 2018).

The common land border between eastern Lithuania and Russia is $266 \mathrm{~km}$ long, the maritime border is another $22.4 \mathrm{~km}$, along which there are now six border crossing points. In view of the intensification of the military exercises of the Russian Federation with Belarus and open political confrontation through the construction of strategic facilities near the borders of Lithuania for the development of the EU energy market (the Nord Stream-2 gas pipeline and the nuclear power plant in Ostrovets, Belarus), in 2017 Lithuania closed two crossing points at the border with the Russian Federation and suspended the simplified border regime for the entry of citizens of the Russian Federation living in the Kaliningrad Oblast.

The highest level of state border protection was reached with the completion of the demarcation of the common border between Lithuania and the Russian Federation, which happened 16 years after the collapse of the USSR: the Protocol on Demarcation of the Border, signed in 2017, entered into force in 2018. Furthermore, unlike Ukraine, whose demarcation of the 2,295 km long common border with the Russian Federation has yet to be completed, Lithuania not only decided to build a fence on the eastern border with the Kaliningrad Oblast of the Russian Federation, but also erected a $45 \mathrm{~km}$ long construction in less than six months at the expense of the national budget.

Lithuania took an active part in resolving problems related to the consequences of the crisis in Ukraine through a series of state programs that since the autumn of 2014 
have been fully funded by the Lithuanian government, that is, even before the migration crisis in the EU. A program is underway to rehabilitate Ukrainian soldiers who need professional help to recover their physical abilities. Usually the rehabilitation period lasts from one to three months; all expenses are covered by the Lithuanian side. In total, almost 200 soldiers went through rehabilitation. Unlike active participation in overcoming the migration crisis in the EU, Lithuania has become one of those EU states that demonstrated strong support for Ukraine, not only from the EU's tribune, but also as real cooperation at all state levels and from financial to professional support.

Since the crisis in 2014, the labor migration of Ukrainian citizens to the Republic of Lithuania grew, and after the signing of the EU visa-free agreement with 2017, growth has increased. However, labor migration involves a temporary (more often seasonal) stay of Ukrainians in Lithuania. To apply for employment permits in Lithuanian companies, it is necessary for Ukrainians to draw up documents under the procedure prescribed for all foreign citizens.

Migrant workers mainly come from Ukraine to fill gaps in the labor market in Lithuania. This primarily concerns truck drivers, builders, welders and butchers, who are mostly male persons. However, the Lithuanian Employers' Confederation does not believe that an increase in immigrants from third countries should be considered as a trend that will have a positive impact on the labor market and economy of Lithuania in the long term: "The outflow of Lithuania's working population will not be solved by an increase in low-skilled people from third countries. High-end specialists are needed. In practice, even Lithuanian emigrants returning to Lithuania are not a panacea, as they have failed outside Lithuania" (Arlauskas, 2019). Such thoughts cannot be considered unambiguous, because the fact that it is easier for a person to realize their work potential within their state is not taken into account: the mentality, language, and environment are paramount factors which determine comfort for any person, but additionally education, professional skills, experience, and the demand for their profession in the country are signs of any person's willingness to realize themselves in the labor market. The example of Presidents of Lithuania, Dalia Grybauskaite and Valdas Adamkus, is a demonstration of the fact that the experience of working abroad, both within the EU and beyond, offers tremendous benefits when the person embarks on a career in their homeland. Knowledge of languages, not only Lithuanian, but also other languages, especially English, is an integral part of a successful working career. However, the task of the Lithuanian government is somewhat more complicated, since the average person needs a job with low and medium responsibility, but also decent pay, so the priority is the issue of economic well-being of the state and the reduction of the cost for maintaining not only its central and municipal apparatus, but also energy supply network, which turns out to be the main factor affecting the wages of an average Lithuanian.

\section{National minorities in Lithuania as a factor of internal stability}

The geopolitical situation of the Baltic states changed after the illegal annexation of the Crimean Peninsula and the conflict in Donbas. The security of their eastern borders, which are also the eastern borders of the EU, was undermined. This led the 
Republic of Lithuania to revise its internal security policy, namely in terms of maintaining stability and integrating national minorities into the public life of the country. In order to prevent the manipulation of information by any actor in the international arena, in 2015 Lithuania renewed the activities of the Department for National Minorities subordinate to the Government of Lithuania, and at the same time approved the relevant Strategic Action Plan for 2016-2018 (Kuczyńska-Zonik, 2017, p. 8). Whereas in Latvia and Estonia the largest national minority is the Russian minority, as of 2017 in Lithuania the largest national minority was Polish (according to the official statistics in Lithuania) (Kuczyńska-Zonik, 2017, p. 31). In 2018, the Ukrainian community in Lithuania is recognized as being larger than the Russian community (nearly 17 thousand people as against 12.5 thousand, respectively) (The largest foreign community in Lithuania is Ukrainian, 2019). The Russian-speaking population in modern Lithuania is concentrated mainly in the districts of the cities of Vilnius and Klaipeda, which are territorially close to the border with Belarus and the Russian Federation. There does not seem to be any threat that this population might support an armed aggression from its eastern neighbors.

In view of the existence of "hybrid" information propaganda, the Lithuanian leadership is occasionally criticized by Russian media for violating the rights of the Polish national minority, in particular the right to study in the ethnic minority language and the rules for writing the surnames of Lithuanian citizens in Polish. According to the National Security Threat Assessment (National Threat Assessment, 2019), Russia maintains cooperation between the Polish and Russian communities, which accuse the Lithuanian leadership of violating the rights of national minorities. When the Polish political party Electoral Action of Poles in Lithuania, led by a prominent Polish activist in Lithuania, Waldemar Tomaszewski, formed a coalition with Lithuanian Russians, it created a negative view of Lithuanian Poles in the eyes of most Lithuanians (Kuczyńska-Zonik, 2017, p. 35). But, in contrast to Latvia and Estonia, Lithuania considers the Russian-speaking population to be weakly consolidated but well assimilated into Lithuanian society. However, Lithuania seeks to integrate national minorities into public life rather than to assimilate them, as assimilation can often cause the loss of unique ethnic characteristics and traditions of the national community.

In its turn, there is a fine line between the integration and assimilation of migrants, because without knowledge of Lithuanian language within the country it is almost impossible to build a political or academic career and, conversely, it is important not to lose one's native language when learning Lithuanian. Therefore, the Lithuanian government's desire to avoid separation, refusing to grant special status or to discriminate against persons with non-Lithuanian origins, or to distinguish between national minorities on linguistic or cultural grounds, while not restricting the development of these unique characteristics by the imperative direct rules of the Lithuanian law, seems quite logical. In this sense, English (as a supranational language of world science, programming, and international treaties) plays the role of a neutralizer to most possible claims made by national minorities, since English lessons at Lithuanian general schools are ensured by the government and dictated rather by the aim of adapting a person (of any ethnic origin) to modernity where speaking foreign languages is desirable, than by the aim of preserving the linguistic and cultural heritage of Lithuania. 
Unlike Estonia and most EU countries, in which long-term strategies for integrating ethnic communities are adopted individually, Lithuania approves such a strategy only for the Roma national minority. The Roma national minority has the most vulnerable position among the national minorities not only in Lithuania but also in Central and Eastern Europe as a whole: not having their own homeland - a country that could preserve and develop the language and culture of the Roma at the legislative level. The European Commission requires special attention to the Roma national minority, not only from Lithuania, but also from all countries where this nation has permanent centers of residence. The ethnic Roma nation has no territorial definition, as it does not belong to any country, and yet is part of the societies of most Central and Eastern European countries. For Lithuania, the issue of sustaining the Roma community had been a challenge even before the association agreement with the EU was signed, and is still subject to monitoring by the Council of Europe in accordance with the obligations under the Framework Convention for the Protection of National Minorities, as well as by the European Commission in terms of implementation at the EU level under the EU Framework for National Roma Integration Strategies up to 2020 (hereinafter referred to as the EU Strategies) (The EU Framework (5.4.2011.COM (2011) 173)).

In fact, the Roma minority is a less numerous ethnic community in Lithuania than Karaim community (2,500 people and about 3,000 people, respectively), but it is the Roma minority in regard to which the monitoring is carried out most thoroughly, and after accession to the EU and approval of the EU Strategies in 2011, the issue of improving the situation of the Roma minority appeared on the political agenda of Lithuania (PI Roma, 2018, p. 7). It should be noted that the issue here is not the development of the Roma language or traditions; the EU-funded activities are more related to the integration of the Roma into Lithuanian society (like in most Central and Eastern European countries) by raising their elementary education level in the state language of the country of residence or another EU language, involvement in public life through employment, and improved living and health conditions. The illiteracy situation of the Roma minority remains unsatisfactory: 18 per cent of men and 35 per cent of women living in Vilnius have poor language competences (Poviliunas, 2011, p. 7). The issue here is solely Lithuanian literacy and grammar: in studies or reports there is no mention of studying in the Roma language. In Lithuania, as in others states, issues of national minorities became the subject of monitoring by the Council of Europe Advisory Committee on the Framework Convention for the Protection of National Minorities, which stated in its conclusions that there was a negative stereotype against the Roma in society, and unequal access to education, employment and healthcare, all of which should be overcome. In addition, education exclusively in Lithuanian, the inability to use their ethnic language in communication with the authorities, the correct spelling of surnames and names in identification documents were defined as discrimination against the rights of national minorities (Second Opinion, 2006; Third Opinion, 2013; Fourth Opinion, 2018).

The situation with the rights and freedoms of other national minorities in Ukraine, namely the Hungarian one, has become similar. Until 2011, there was also a law in Lithuania that allowed a person to study at school of a national minority in the ethnic language. However, in order to preserve the Lithuanian language within the country, a preventative method was adopted which increased the amount of teaching time in the Lithuanian 
language and included the subject "Lithuanian language" in the obligatory final exams. Ukraine also adopted a new law on education in 2016 to increase the teaching time in Ukrainian at the schools of national minorities and to introduce a Ukrainian language exam. Unlike Ukraine, Lithuania and Latvia have already acquired EU membership and, importantly, political weight among other EU members. Ukraine, in a situation similar to the dissatisfaction of the Polish-speaking population in Lithuania, was criticized by and faced real counter-measures from the Hungarian leadership (for example, by obstructing meetings of the Ukraine-NATO Commission or, moreover, the latest Hungarian Foreign Minister's statement about blocking Ukraine's prospective membership in NATO due to the Ukrainian language law $^{1}$ ). In this regard, the argument that "the issue of state language remains politicized; politicians are eager to use it, comparing with other policies" (Hordecki, 2019, p. 91) should be rightfully supplemented with the assertion that politicizing is used by politicians on the national level in the same way that it is used by states in international relations.

However, there is no direct support for Hungary's claims with regard to Ukraine in Brussels. The issue of the development and promotion of the national language lies within the sphere of national issues and, just like the issue of energy security for EU member states, is resolved within the national interests of each state.

In 2001, the State Commission for Lithuanian Language was specially established in Lithuania, and its powers include not only the control of linguistic culture, but also the punishment for illiterate writing in public. For Ukraine, such an example has already become useful in terms of promoting the Ukrainian language in order to avoid problems with European partners, precisely from the standpoint of enhancing its authority as one that needs "preservation" for the identity of the nation. After all, every national minority living in Lithuania or in Ukraine has a center - its homeland - where their ethnic language is official and, accordingly, has the conditions for support and development. In 2019 , by analogy, a similar commission was established in Ukraine and it started to work in November (The Law of Ukraine, 2019, p. 81). The official Lithuanian language's development and popularization is also relevant and constitutes part of the overall migration policy of the country, as the young people of Lithuania move to other EU countries for various reasons and the use of the Lithuanian language is limited to the territory of Lithuania. Like the Ukrainian language, it has no international status. Lithuania's experience in terms of the use and development of the official state language, in addition to the languages of the largest national groups in the country (Polish and Russian speaking ones), demonstrates the practical steps that can be taken to prevent conflicts in this context.

Furthermore, numerous Honorary Consulates of Lithuania in the cities of most countries of the world (for example, in Ukraine, in addition to the Embassy of Lithuania, there are 10 consulates in different regional cities) can be noted as making a significant contribution to the spread of the "soft power" of the Republic of Lithuania. This institution's aim is not only the development of socio-economic cooperation between states, but also cultural and humanitarian development. Usually such institutions have close links with

\footnotetext{
${ }^{1}$ Hungary to block Ukraine's NATO membership over language law, "Reuters", https://www. reuters.com/article/us-ukraine-nato-hungary/hungary-to-block-ukraines-nato-membership-over-language-law-idUSKBN1Y823N?feedType=RSS\&feedName=worldNews.
} 
Lithuanian communities (diasporas) in those cities or their associations, and financially support the ethnic and cultural activities in which the citizens of the host country are involved. In particular, keeping in touch with Lithuanians abroad and trying to promote Lithuanian culture encourages Lithuanians to learn the language and return to Lithuania for permanent residence. A striking example of returning to Lithuania to fulfil himself as a Lithuanian citizen after 47 years of residence in the United States could be President of Lithuania in 1998-2003 and 2004-2009, Valdas Adamkus.

The matter of dual citizenship, a controversial issue that divides not only Lithuanian politicians, but also the civil society of the Republic as a whole, was submitted to a national referendum (in May 2019). Although the Lithuanian passport ranked 30 out of 100 under the "opportunities" Index in 2018, dual citizenship could be an additional preference for Lithuanians abroad and foreigners who wish to develop their business in Lithuania.

The issue of dual citizenship is not included in the list of tasks of the state program "Global Lithuania." However, it was and remains relevant among both Lithuanian politicians and representatives of the diaspora. The issue of dual citizenship as a preference for foreign Lithuanians who acquired the citizenship of another state during emigration and for immigrants from third countries has been debated for many years. However, as in Latvia, there will be certain criteria for countries whose citizenship might be eligible: the EU, NATO, OSCE (31 countries, except the Russian Federation, though it is a member of the OSCE), separate bilateral agreements on mutual recognition of dual citizenship and exclusive cases. Unlike Latvia, where citizenship can be obtained in exchange for the purchase of real estate or significant investments, such procedures are not required for obtaining Lithuanian citizenship. The exception is the President of Lithuania's right to grant Lithuanian citizenship to persons for special services to the country, without the obligation to renounce their second citizenship. The model is almost identical to the procedure for granting citizenship in Ukraine - by a separate decree of the President of Ukraine. A striking example of the real control and enforcement of Lithuanian citizenship laws (in this case, sufficient grounds for granting citizenship for services to the Lithuanian state) was the impeachment process of third President of Lithuania, President Roland Paksas (February 2003-April 2004). ${ }^{2}$

Attempts to hold a referendum on the issue of dual citizenship were made several times during Lithuania's EU membership, but, for example, in 2011 diaspora representatives themselves rejected the referendum proposal made by the government because of the costs required for such an event and the insufficient time to carry out an information campaign for Lithuanian foreigners regarding the preferences of dual citizens (Lithuania: EU resettlement programme triggers national social inclusion challenges, 2016, p. 332). In 2018, the initiative to hold a referendum on dual citizenship was submitted to the Seimas by representatives of the political party Union of Christians and Greens of Lithuania. The referendum was set in parallel with the May 2019 presidential election and candidates could use it as a tool to manipulate voters' opinions, politicizing this

${ }^{2}$ In 2003, during the Lithuanian Constitutional Court's impeachment proceedings in relation to President Roland Paksas, the Court declared the President's order to grant Lithuanian citizenship to a person (Russian citizen) unconstitutional, and recognized the citizenship as "payment" for illegal financial support during the presidential campaign. 
democratic institution through discussing the issue in such terms. The majority said no to the question in the referendum. Dual citizenship has become a current topic in Ukraine due to the reality of such an opportunity for foreign Ukrainians in the near future, but without a national referendum.

\section{Conclusions}

The EU migration crisis has enabled Lithuania to demonstrate its own political stance on disagreeing with the European Commission's quota relocation system as a tool for overcoming the crisis. Ukraine itself offered to accept refugees from the EU, in spite of the crisis in the country. Despite numerous commitments of Ukraine under the Association Agreement with the EU, which require a thorough reform of most public administration systems, including border security, and social systems, additional new workloads are not justified in terms of obtaining preferences for EU membership or at least experience in dealing with migration crisis, as almost all the countries from which refugees arrived illegally in the EU are countries of migration risk for Ukraine.

Lithuania's geopolitical location makes the country vulnerable to a real and potential threat of illegal migration from the south-eastern side of the country's border, to the part of the northern EU border, so the focus of border protection is focused on the EU's neighboring third countries (Belarus, Russia, and Ukraine). Unlike Lithuania, Ukraine has not completed the demarcation of the common border with the Russian Federation, which needs to be done in the immediate future, not only for accession to the EU, but also for security reasons.

Labor migration (legal and illegal) is increasing both in Lithuania and in Ukraine. Lithuanians are moving to more developed countries, Ukrainians are migrating, inter alia, to Lithuania as a country with better economic conditions. Ukraine's economic development may not be enough for Ukrainians to return to the country, even after Ukraine's accession to the EU. Today, Ukraine needs economic growth, manufacturing and industrial development.

Lithuania's national security has become more vulnerable due to events in Ukraine that have provoked not only an update to the policy and action to protect the state border in the east, but also a new strategy for the protection of the rights and freedoms of national minorities. Lithuania is taking steps to deepen the trust between the state and national minorities in order to avoid ambiguous behavior by their representatives both as regards the government's policies as a whole, and in the event of armed external aggression. The inviolability of the state border in eastern Lithuania, which is common with Russia, is additionally determined by a separate protocol on its demarcation during the crisis in Ukraine. The reinforcement of the border with an additional fence at the initiative of the Lithuanian government in 2018 became the final stage in the protection of the Lithuanian part of the EU's eastern border.

The Russian-speaking population, as a heritage of generations of the Soviet past, is not considered a potential threat to the country's internal security. Despite a political information war on the part of the Russian media, the Lithuanian leadership is confident in the complete assimilation of its Russian minority into Lithuanian society, although this 
process took place without the intervention of the state. The state sees the integration of national minorities as a guarantee for the free development of ethnic peoples, without loss of self-identification.

Although there is a number of problems in respecting the rights of national minorities in the Republic of Lithuania, it pursues a consistent and targeted policy for the maintenance and development of the Lithuanian language. Given the similarity of the situation in Ukraine, where the Hungarian national minority accuses the Ukrainian authorities of narrowing their rights and freedoms, it would be advisable to close this issue before the accession to the EU. After all Hungary's counteraction is more detrimental to UkraineEU and Ukraine-NATO relations than to the fruitless efforts to hold a high-level diplomatic Ukrainian-Hungarian dialogue.

\section{Bibliography}

Action Plan for Roma Integration into The Lithuanian Society for 2015-2020, approved by the Minister of Culture of the Republic of Lithuania Order No IV-48 of 29 January 2015 (amended by the Minister of Culture of the Republic of Lithuania Order No IV-273 of 28 April 2015, https://Ec.Europa.Eu/Info/Sites/Info/Files/Lithuania_National_Strategy_2015-2020_En.pdf, 11.09.2019.

Action Plan for Roma Integration into The Lithuanian Society for 2012-2014, https://ec.europa.eu/ info/files/lithuania-national-strategy-2012-2014_en, 11.09.2019.

An EU Framework for National Roma Integration Strategies up to 2020 (5.4.2011.COM(2011) 173 final), Communication from the Commission to the European Parliament, the Council, the European Economic and Social Committee and the Committee of the Regions, https://eur-lex. europa.eu/legal-content/EN/TXT/PDF/?uri=CELEX:52011DC0173\&from=en, 18.09.2019.

Arlauskas D. (2019), On the "pitfalls" of immigration from third countries. Immigration to Lithuania increases: who are the immigrants?, 27.06.2019, "Lithuanian Tribune", https://lithuaniatribune.com/immigration-to-lithuania-going-up/, 17.08.2019.

Brunovskis A., Sønsterudbråten S. (2017), Asylum, integration and irregular migration in Lithuania: Policy and practice at the edge of the European Union, FAFO social science research foundation, https://www.fafo.no/images/pub/2017/20631.pdf, 17.08.2019.

de Haas H. (2009), Migration systems formation and decline. A theoretical inquiry into the self-perpetuating and self-undermining dynamics of migration processes, "International Migration Institute Working Paper", no. 19, University of Oxford.

EU Heads of State agree to step up the fight against illegal migration (2018), "Press Service of the President of Lithuania", 29.06.2018, https://www.lrp.lt/ru/press-centr/soobscenija-dlja-pressy/ glavy-stran-es-dogovorilis-usilit-borbu-s-nelegalnoi-migraciei/30340, 25.11.2019.

European Solidarity: A Refugee Relocation System (2015), European Commission, https://ec.europa. eu/home-affairs/sites/homeaffairs/files/what-we-do/policies/european-agenda-migration/background-information/docs/2_eu_solidarity_a_refugee_relocation_system_en.pdf, 2.09.2019.

Fourth Opinion on Lithuania (2018), Advisory Committee on the Framework Convention for the protection of national minorities (ACFC/OP/IV(2018)004), https://Rm.Coe.Int/4th-AdvisoryCommitee-Opinion-On-Lithuania-English-Language-Version/1680906d97,29.08.2019.

Geddes A., Scholten P. (2016), The politics of migration and immigration in Europe, $2^{\text {nd }}$ Edition, SAGE Publications, London.

Hordecki B. (2019), Language Policies as an Instrument of Shaping and Rhetoricizing Mutual Relations in the Post-Soviet region, "Przegląd Politologiczny", vol. 2, DOI: 10.14746/pp.2019.24.2.6, http://przeglad.amu.edu.pl/wp-content/uploads/2019/06/pp-2019-2-06.pdf, 30.11.2019. 
Hungary to block Ukraine's NATO membership over language law, "Reuters", https://www.reuters. com/article/us-ukraine-nato-hungary/hungary-to-block-ukraines-nato-membership-over-language-law-idUSKBN1Y823N?feedType=RSS\&feedName=worldNews.

Jakučionis S. (2018), As EU changes asylum system, Lithuania continues disapproval of migrant quotas, 26.01.2018, "Baltic News Service", https://en.delfi.lt/eu/as-eu-changes-asylum-systemlithuania-continues-disapproval-of-migrant-quotas.d?id=77005205, 21.11.2019.

Kuczyńska-Zonik A. (2017), The securitization of national minorities in the Baltic States, "Baltic Journal of Law \& Politics", vol. 10, no. 2.

Lithuania: EU resettlement programme triggers national social inclusion challenges, 8.02.2016, "European web site of integration", https://ec.europa.eu/migrant-integration/news/lithuania-euresettlement-programme-triggers-national-social-inclusion-challenges, 25.11.2019.

Massey Douglass S., Arango J., Hugo G., Kouaci A., Pellegrino A., Taylor J. E. (1993), Theories of international migration: a review and appraisal, "Population and Development Review", 19(3).

Minister of Internal Affairs of Lithuania Misuunas E. (2018), Relocation of Refugees to Lithuania Slows Down Due to Lack of Documents from Greece and Italy, 07.09.2018, "Lithuanian Courier", no. 4, http://www.kurier.lt/ministr-peremeshhenie-bezhencev-v-litvu-buksuet-iz-za-nexvatki-dokumentov-ot-grecii-i-italii/, 21.11.2019.

National Threat Assessment (2019), State Security Department of the Republic of Lithuania, https:// www.vsd.lt/wp-content/uploads/2019/02/2019-Gresmes-internetui-EN.pdf.

Perring R. (2016), Desperate EU urges nations to accept migrant quotas as Baltic states close borders, 9.08.2016, "Express", https://www.express.co.uk/news/world/698025/Baltic-states-EUmigrant-quote-Latvia-Lithuania-Estonia, 12.08.2019.

PI Roma Community Centre Civil society (2018), Monitoring report on implementation of the national Roma integration strategies in Lithuania, European Commission B-1049 Brussels.

Poviliunas A. (2011), Promoting Social Inclusion of Roma in Lithuania, A Study of National Policies, European Commission DG Employment, Social Affairs and Inclusion, https://www.gitanos. org/upload/44/11/synthesis_report_2011-2_final_3_1_.pdf.

Prawo Ukrainy co do zabezpieczenia funkcjonowania języka ukraińskiego jako języka państwowego, (2019), "Dziennik Ustaw Rady Najwyższej” (Vidomosti Verhovnoi Rady Ukrainy), no. 21.

Second Opinion on Lithuania (2006) (ACFC/SR/II9(2006)007), Advisory Committee on The Framework Convention for The Protection of National Minorities, http://tandis.odihr.pl/explore?bitstream $\mathrm{id}=22644 \&$ handle $=20.500 .12389 / 19771 \&$ provider $=$ iiif-image $\# ? \mathrm{c}=0 \& \mathrm{~m}=0 \& \mathrm{~s}=$ $0 \& \mathrm{cv}=9 \& \mathrm{xywh}=-1332 \% 2 \mathrm{C}-200 \% 2 \mathrm{C} 5132 \% 2 \mathrm{C} 3897,29.08 .2019$.

The largest foreign community in Lithuania is Ukrainian, 19.01.2019, "Delfi.lt.", https://ru.delfi.lt/ news/live/krupnejshaya-obschina-inostrancev-v-litveukrainskaya.d?id=80142265, 11.08.2019.

Third Opinion on Lithuania (2013) (ACFC/OP/III (2013)005), Advisory Committee on The Framework Convention for The Protection of National Minorities https://rm.coe.int/CoERMPublicCommonSearchServices/DisplayDCTMContent?documentId=0900001680099360, 29.08.2019.

\section{Polityka migracyjna i mniejszości narodowe w Republice Litewskiej: lekcje dla Ukrainy}

\section{Streszczenie}

Celem artykułu jest określenie czynników, które wpłynęły na proces opracowywania i realizacji litewskiej polityki zagranicznej i krajowej w zakresie migracji w ramach przepisów UE (dyspozycyjnych i imperatywnych) oraz wskazanie tych czynników, które mogą mieć podobny wpływ na stabilność procesów migracyjnych na Ukrainie w związku z jej przystąpieniem do UE. Zadanie polega na określeniu problemów (negatywnych uwarunkowań i konsekwencji) sektora migracji w oparciu o analizę ponad 
dekady doświadczeń Litwy jako członka UE oraz wpływu ostatniego kryzysu europejskiego. Strategie Litwy w odniesieniu do następujących zagadnień są istotne dla aspiracji Ukrainy w zakresie integracji europejskiej: kryzys migracyjny w UE, w zakresie przezwyciężenia go poprzez „plan relokacji”; oraz integracja mniejszości narodowych Litwy, w tym mniejszości romskiej, ze społeczeństwem obywatelskim kraju. Ponadto, niektóre wysiłki Litwy aktywnie wspierają aspiracje Ukrainy w zakresie integracji europejskiej, takie jak próba modelowania, w jaki sposób Ukraina może przewidywać i rozwiązywać bieżące problemy w przypadku uzyskania członkostwa w UE, na podstawie doświadczeń Litwy, co ma znaczenie dla Ukrainy ze względu na fakt, że Litwa i Ukraina - wraz z Polską i innymi krajami - odziedziczyły sowiecki system rządów, a także ze względu na ich podobną mentalność i obecne stosunki dwustronne. Po kryzysie ukraińskim w 2014 roku, a następnie kryzysie migracyjnym UE w 2015 roku, Litwa zrewidowała swoje priorytety polityki krajowej, biorąc pod uwagę, że jej granica państwowa jest częścią granicy UE, bez żadnej „strefy buforowej”.

Słowa kluczowe: Republika Litewska, polityka migracyjna, kryzys migracyjny UE, mniejszości narodowe, imigracja, rozwój języka państwowego 
